\title{
Bentuk dan Makna Gong Timor dalam Upacara Ritual Tfua Ton di Napan
}

\author{
Sunarto \\ Agustinus Renaldus Afoan Elu ${ }^{1}$ \\ Jurusan Sendratasik, Universitas Timor
}

Jurusan Sendratasik, Fakultas Bahasa dan Seni, Universitas Negeri Semarang

\begin{abstract}
The Form and Meaning of Gong Timor on the Ritual Ceremony of Tfua Ton in Napan. This paper aims to understand the rhythmic musical form of Gong Timor in the Tfua Ton ritual based on the rhythm elements contained in it and to understand more deeply the symbolic meaning of Gong Timor in the Tfua Ton ritual. The research method uses descriptive qualitative research design with phenomenology. Research data were collected using observation, interview and document study techniques. The data analysis technique was done through the process of reduction, presentation, and concluding. The results of this study indicate that the Gong Timor music form consists of several elements of rhythm, namely beats, accents and rhythm patterns. The symbolic meaning contained in the Gong Timor in the Tfua Ton ritual ceremony is as a symbol of communication, strength, character, and identity of the people of Napan Village. The symbol is interpreted by the struggle of the community in fighting for lives and economic needs. In the ritual, Gong Timor is interpreted as a liaison among the community and the ancestors, and nature that inhabit the place. The Gong Timor has a symbolic meaning that can only be understood by the local community. Gong Timor in the Tfua Ton ritual ceremony has become an inseparable unit.
\end{abstract}

Keywords: Gong Timor; Tfua Ton; symbolic meaning

\begin{abstract}
ABSTRAK
Tulisan ini bertujuan untuk memahami tentang bentuk musik ritmik Gong Timor dalam upacara ritual Tfua Ton berdasarkan elemen-elemen irama yang terkandung didalamnya serta memahami lebih dalam tentang makna simbolik Gong Timor dalam upacara ritual Tfua Ton. Metode penelitian menggunakan kualitatif deskriptif dengan desain penelitian fenomenologi. Data penelitian dikumpulkan dengan menggunakan teknik observasi, wawancara dan studi dokumen. Teknik analisis data dilakukan melalui proses reduksi, penyajian dan penarikan kesimpulan. Hasil penelitian ini menunjukan bahwa, bentuk musik Gong Timor terdiri dari beberapa elemen irama yaitu ketukan, aksen dan pola irama. Makna simbolik yang terkandung pada Gong Timor dalam upacara ritual Tfua Ton yaitu sebagai simbol komunikasi, keperkasaan, karakter dan identitas masyarakat Desa Napan. Simbol tersebut dimaknai dengan adanya perjuangan masyarakat dalam memperjuangkan kehidupan dan kebutuhan ekonomi masyarakat setempat. Dalam ritual tersebut Gong Timor dimaknai sebagai penghubung antara masyarakat dengan para leluhur dan alam yang mendiami tempat tersebut. Gong Timor tersebut mamiliki makna simbolik yang hanya bisa dipahami oleh masyarakat setempat. Gong Timor dalam upacara ritual Tfua Ton telah menjadi satu kesatuan yang tidak dapat dipisahkan.
\end{abstract}

Kata kunci: Gong Timor; Tfua Ton; makna simbolik

\footnotetext{
Alamat korespondensi: Jurusan Sendratasik, Universitas Timor. Jln. Eltari Km. 9, Sasi, Kefamenanu, Timor Tengah Utara, Nusa Tenggara Timur 85613.
} 


\section{Pendahuluan}

Musik tradisional Gong Timor merupakan salah satu alat musik ritmik yang juga berfungsi sebagai sarana dalam ritual adat masyarakat Desa Napan. Secara teoritis Gong termasuk kedalam jenis alat musik Idiophone yang sumber bunyinya berasal dari alat musik itu sendiri. Alat musik ini terdiri dari beberapa bagian yaitu Tonu Mese, yaitu satu buah Gong yang berukuran kecil, Ote, yaitu 2 buah Gong yang berukuran sedang dan Kbola, yaitu 2 buah Gong yang berukuran besar dan satu buah alat musik Gendang yang biasanya di sebut dengan sebutan Kée. Gong Timor ini biasanya digunakan oleh masyarakat Napan pada saat acara atau kegiatan-kegiatan yang berhubungan dengan ritual adat. Salah satunya ialah ritual Tfua Ton yang dilaksanakan oleh masyarakat Napan setiap tahunnya pada bulan November.

Setiap daerah pastinya memiliki tradisi dan kepercayaan yang berbeda-beda. Berkembangnya suatu kesenian itu tergantung pada masyarakat pendukungnya (Tindaon, Rosmegawaty, 2018). Hal ini juga dapat berpengaruh pada pola pikir masyarakat dalam memenuhi suatu kebutuhan hidup. (Triyanto, 2018) menjelaskan bahwa manusia sebagai makhluk sosial, manusia tidak dapat menjalani kehidupan sosialnya tanpa menyatu dalam satu kesatuan kolektif dengan kesepakatan bersama dalam membentuk sistem adat istiadat yang mengikat dan menjadi identitas bersama sebagai pranata untuk berinteraksi secara berkelanjutan dalam melangsungkan hidup dan kehidupannya. Tfua Ton merupakan salah satu cara mereka dalam memenuhi kebutuhan hidup dan sarana masyarakat setempat, yaitu dengan memohon kepada Tuhan, Leluhur dan Alam untuk dapat membantu mereka dalam memenuhi segala kebutuhan mereka.

Ritus Tfua Ton adalah salah satu upacara ritual masyarakat Timor Dawan terhadap Uis Neno dan Uis Pah sebagai penguasa langit dan bumi. Upacara ritual ini dilaksanakan pada saat masyarakat Timor Dawan hendak mempersiapkan lahan pertanian yang baru maupun syukur atas panenan yang baru. Ritus Tfua Ton merupakan salah satu ritus untuk memohon turunnya hujan, untuk memohon ulan fua faon-sen sene fua faon dan juga sebagai upacara Tahun Baru bagi para petani. Tahun baru yang dimaksudkan disini ialah sebagai awal untuk memulai musim tanam. Ritus Tfua Ton ini merupakan ritus yang mengungkapkan hubungan manusia dengan Wujud Tertinggi/Uis Neno.

Gong Timor dalam upacara ritual Tfua Ton berfungsi sebagai salah satu sarana yang dimainkan pada pada saat upacara berlangsung. Menurut kepercayaan masyarakat Desa Napan, Gong Timor yang dimainkan saat upacara ritual adalah sebagai sapaan dan penghormatan kepada para leluhur yang telah meninggal. Selain itu juga, dapat berfungsi untuk memanggil para leluhur untuk hadir bersama-sama dengan mereka dalam upacara ritual tersebut.

Kehadiran musik Gong Timor dalam upacara ritual Tfua Ton merupakan fenomena budaya yang unik dan menarik. Dikatakan menarik karena masyarakat setempat masih memfungsikannya hingga sekarang ini. Gong Timor sendiri dalam pelaksanaan upacara ritual Tfua Ton selalu dimainkan. Berdasarkan fenomena yang terjadi, penulis tertarik untuk membahas lebih dalam mengenai alat musik Gong Timor dalam ritual Tfua Ton dengan beberapa alasan mendasar yaitu: 1) Gong Timor dalam upacara ritual Tfua Ton memiliki bentuk dan makna yang merupakan lambang identitas internal dan eksternal atau yang membedakan antara masyarakat Napan dengan etnik lainnya; 2) selain sebagai identitas masyarakat, Gong Timor dalam upacara ritual Tfua Ton perlu untuk dilestarikan dan dikembangkan; 3) Gong Timor dalam upacara ritual Tfua Ton terkandung beberapa nilai yang universal seperti, kerjasama, saling menghormati, interaksi sosial dan sebagainya. Hal ini dapat digunakan sebagai dasar dalam merancang Gong Timor dalam upacara ritual Tfua Ton di Desa Napan Kabupaten Timor Tengah Utara dengan kajian fungsi dan makna model pendidikan karakter; 4) Belum ada buku yang mengkaji secara khusus tentang bentuk, fungsi dan makna Gong Timor dalam upacara ritual Tfua Ton;dan 5) Penulis tertarik untuk mendeskripsikan dan menganalisis sekaligus memperkenalkan dan mempromosikan Gong Timor dalam upacara ritual Tfua Ton kepada masyarakat. 
Berdasarkan latar belakang tersebut maka penulis akan membahas lebih dalam terkait bentuk dan makna musik Gong Timor dalam upacara ritual Tfua Ton di Desa Napan. Untuk menganalisis permasalahan tersebut penulis menggunakan teori makna simbolik oleh Susane K. Langer. Dalam teori tersebut dikatakan bahwa simbol dibedakan menjadi dua macam, yaitu simbol presentasional, dan simbol diskursif (Langer, 1957:25). Simbol presentasional adalah simbol yang cara penangkapannya tidak membutuhkan intelek, dengan spontan simbol itu menghadirkan apa yang dikandungnya (Sunarman, 2010:15). Sedangkan simbol diskursif adalah simbol yang cara penangkapannya menggunakan intelek, tidak secara spontan, tetapi berurutan. Selain itu simbol juga dibedakan menurut cara pemakaiannya, yaitu: bahasa, ritus, mitos dan musik. Lebih lanjut bahwa bentuk-bentuk simbolik itu adalah bahasa, mitos, seni dan agama. Bentuk lambang atau simbol dapat berupa bahasa (cerita, perumpamaan, pantun, syair, peribahasa), gerak tubuh (tari), suara atau bunyi (lagu,musik), warna dan rupa (lukisan, hiasan, ukiran, bangunan).

Pendekatan yang digunakan dalam penelitian ini adalah kualitatif deskriptif yang secara rinci menggunakan desain penelitian fenomenologi. Disain penelitian ini digunakan untuk meneliti fenomena yang terjadi yaitu tentang Gong Timor dalam upacara ritual Tfua Ton. Fokus dari penelitian ini ialah bentuk musik dan makna musik Gong Timor dalam upacara ritual Tfua Ton di Desa Napan, Kabupaten Timor Tengah Utara. Data penelitian dikumpulkan dengan menggunakan teknik observasi, wawancara dan dokumentasi. Analisis data dengan menggunakan reduksi data, penyajian data dan penarikan kesimpulan.

\section{Upacara Ritual Tfua Ton}

Ritus Tfua Ton merupakan upacara tradisi yang telah diwariskan budaya leluhur yang diturunkan dari generasi ke generasi. Ritual tersebut sangat penting bagi masyarakat Desa Napan khususnya bagi para petani karena dapat memberi jaminan dan kepastian akan adanya musim yang baik. Tujuan diadakannya ritual Tfua Ton ialah untuk memohon turunnya hujan, memohon ulan fua faun-sen sene fua faun dan sebagai tahun baru para petani. Selain itu ritual Tfua Ton juga sebagai suatu upacara syukuran atas anugerah Tuhan lewat pen fini-aen fini yang telah ditanam agar nantinya memberikan hasil yang memuaskan. pen fini-aen fini merupakan bibit dari tanaman tahun yang lalu dan diadakan upacara dengan harapan bahwa dalam satu tahun kedepan akan mendapatkan hasil panen yang lebih baik. Ritual tersebut diadakan setiap tahun sekali pada bulan November.

Ritus Tfua Ton ini ditujukan kepada Uis Neno yang dikenal dengan Uis Neno Mnanu dan Uis Neno Pala. Uis Neno Mnanu adalah Tuhan langit, Dialah yang bercahaya (apinat) yang berarti bernyalanyala, (aklahat) yaitu Dialah yang menciptakan segala sesuatu. Dialah yang menaungi dan memberi hidup kepada manusia melalui kesuburan Uis Neno Pala. Uis Neno Mnanu sering diidentikan dengan matahari (manas) atau yang memberi hidup. Uis Neno Pala adalah Tuhan Tanah, Uis Pah. Dialah Uis Neno kesuburan tanah. Dialah pembawa kebenaran dan kedamaian (Tetus ma Nit), kesejukan dan kenyamanan (Manikin ma Oetene). Singkatnya dialah pembawa keselamatan dan kesejahteraan.

Masyarakat Desa Napan mengartikan Tfua Ton sebagai upacara tahun baru yang dikhususkan bagi para petani, yaitu sebagai awal untuk bercocok tanam. Ini dilakukan sebagai cara mereka untuk meminta berkat kepada Tuhan dan Alam untuk dapat menurunkan hujan yang cukup sehingga dapat menghasilkan panen yang baik. Selain itu juga masyarakat menggunakan Gong Timor sebagai cara untuk menghormati dan menghargai para leluhur yang telah meninggal. Selain itu juga Gong Timor dipercaya memiliki kekuatan mistis yang dapat memanggil jiwa-jiwa para leluhur yang telah meninggal.

Ritual Tfua Ton dilakukan dengan beberapa tahapan. Pertama,tahap persiapan di mana tokohtokoh masyarakat mulai menyiapkan tempat dengan membuat tenda sebagai tempat untuk menyimpan perlengkapan ritual adat. Kedua, proses pelaksanaan ritual adat, proses pelaksanaan dilakukan selama tiga hari yaitu pada hari pertama tua-tua adat melakukan ritual di rumah adat dengan tujuan untuk mengeluarkan segala perlengkapan adat yang 
akan digunakan pada saat ritual di kampung adat. Pada hari kedua, diawali dengan misa perayaan ekaristi dalam ajaran Katholik kemudian pada hari ketiga, merupakan puncak dari kegiatan tersebut yaitu dimulai dengan permainan alat musik Gong Timor, kemudian tua adat menyampaikan tuturan adat di atas Batu Napan dan setelah itu masyarakat mulai menyembelih hewan kurban dari masingmasing suku. Setelah dilakukan penyembelihan tua-tua adat dan atoin amaf berjalan menuju puncak Batu Napan yang merupakan akhir dari ritual adat tersebut. Di puncak Batu Napan tersebut tua adat menyampaikan tuturan adat kepada Tuhan, alam, dan leluhur untuk meminta hujan dengan menggunakan kain hitam. Kain hitam tersebut dilambangkan sebagai awan. Setelah selesai masyarakat Desa Napan mengakhirinya dengan makan dan minum bersama.

\section{Bentuk Ritmik Musik Gong Timor}

Ritme adalah urutan rangkaian gerak yang menjadi unsur dasar dalam musik, bunyi dalam musik membentuk irama dengan bermacammacam lamanya waktu dan panjang-pendeknya bunyi yang dihasilkan (Jatmiko, 2015; Vuust, dkk, 2009). Gong Timor merupakan jenis alat musik ritmis yang tergolong dalam kelompok idiophone yaitu alat musik yang sumber bunyi berasal dari badan alat musik itu sendiri. Cara memainkan alat musik ini ialah dipukul dengan menggunakan kayu. Dalam permainan alat musik ini dibutuhkan keterampilan khusus sehingga dapat menghasilkan bunyi yang baik serta dapat membentuk harmonisasi dari masing-masing Gong

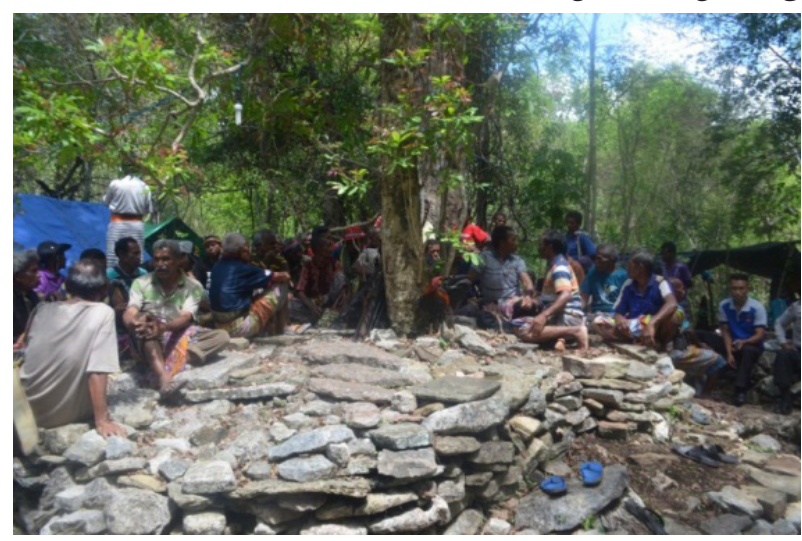

Gambar 1. Pelaksanaan ritual Tfua Ton di atas Batu Napan. (Sumber: Agustinus Renaldus Afoan Elu, 2018)
Timor yang dibunyikan.

Gong Timor tergolong ke dalam beberapa bagian antara lain Gong Tonu mese yang terdiri dari satu buah gong, Ote yang terdiri dari dua buah gong sedang dan Kbola yang terdiri dari dua buah gong besar. Gong Timor merupakan alat musik yang bernada tapi tidak beraturan. Motif ritmik yang dimainkan terkadang berubah-ubah dan tidak tetap. Seperti yang dijelaskan oleh narasumber Ibu Theresia pada tanggal 23 April 2019, bahwa:

Untuk memainkan Gong Timor harus bisa merasakan iramanya yaitu pada gong tonu mese yang menjadi kunci utama. Yang menjadi inti itu adalah tonu mese, sedangkan yang lainnya hanya sebagai pelengkap dan pengiring.

Gong Timor memiliki ukuran diameter dan ketebalan yang berbeda-beda ini berpengaruh terhadap bunyi yang akan dihasilkan oleh alat musik tersebut. Berikut peneliti akan memaparkan terkait ukuran dari alat musik Gong Timor.

Gong pada gambar 3 memiliki ukuran diameter $70 \mathrm{~cm}$ dan ketebalan $4 \mathrm{~cm}$, dengan ukuran


\section{Tonu Mese}

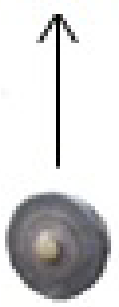

Gambar 2. Susunan Gong Timur. (Sumber: Sunarto, 2018)

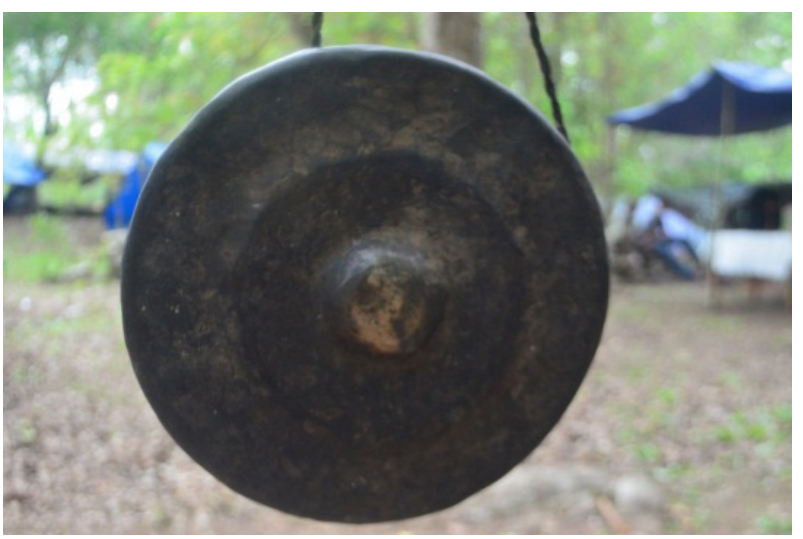

Gambar 3. Gong Tonu Mese.

(Sumber: Sunarto, 2018) 
lebar $22 \mathrm{~cm}$. Sedangkan kedua gong pada gambar 4 memiliki ukuran diameter yang berbeda, gong yang berada di bagian atas memiliki ukuran diameter $76 \mathrm{~cm}$ sedangkan yang bagian bawah memiliki ukuran $78 \mathrm{~cm}$. Lebar dari masing-masing gong memiliki ukuran yang sama yaitu $25 \mathrm{~cm}$ dan memiliki ketebalan $4 \mathrm{~cm}$.

Untuk gong pada gambar 5 keduanya memiliki ukuran diameter dan lebar yang berbeda. Pada bagian atas memiliki diameter $74 \mathrm{~cm}$ sedangkan

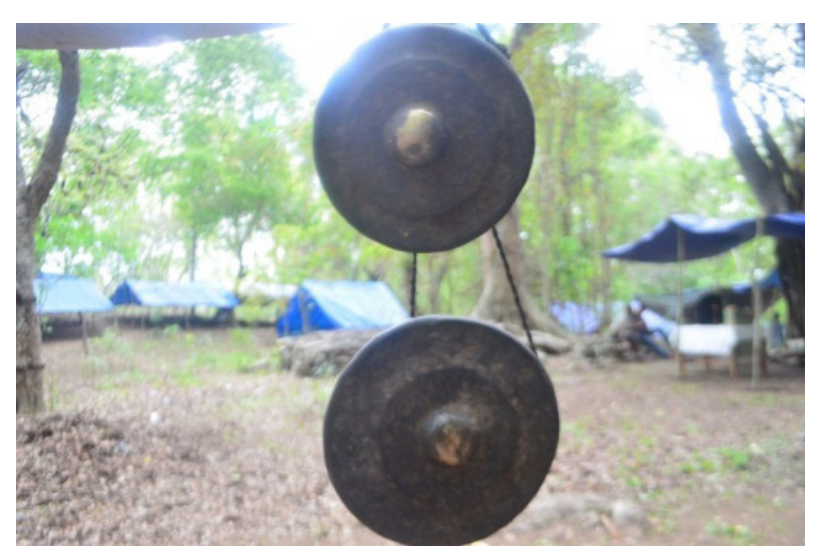

Gambar 4. Gong Kbola.

(Sumber: Sunarto, 2018)

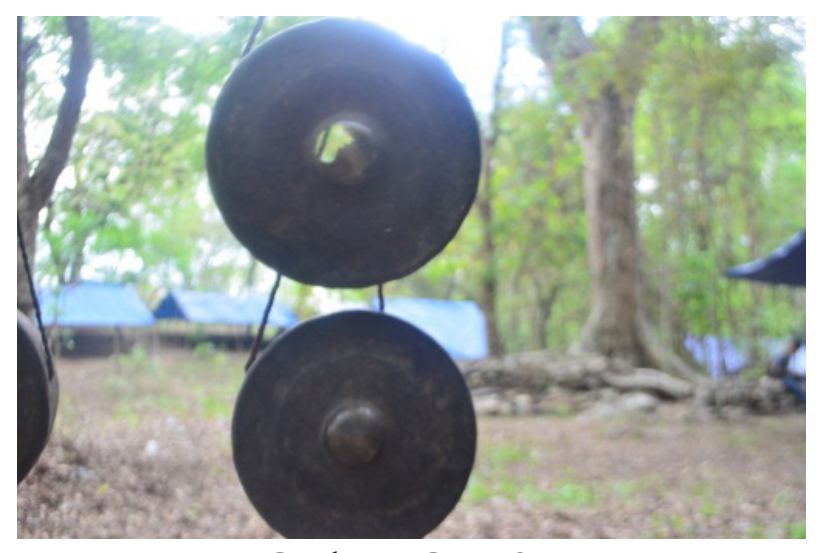

Gambar 5. Gong Ote.

(Sumber: Peneliti, 2018)

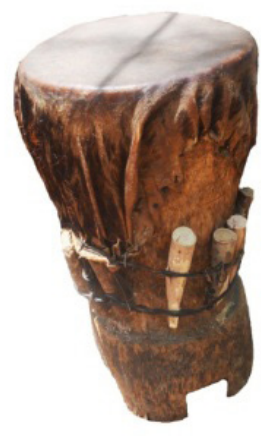

Gambar 6. Gendang (Kèe).

(Sumber: Sunarto, 2018) yang bawah $70 \mathrm{~cm}$. Lebar dari masing-masing gong adalah bagian atas memiliki lebar $25 \mathrm{~cm}$ dan ketebalan $4 \mathrm{~cm}$ dan bagian bawah memiliki lebar $23 \mathrm{~cm}$ dan ketebalan $4 \mathrm{~cm}$.

Gendang (Kée) merupakan salah satu alat musik ritmis yang dimainkan dengan cara dipukul menggunakan tangan. Alat ini dimainkan bersamaan dengan Gong Timor yang berfungsi sebagai penentu tempo. Kè e ini dimainkan oleh 4 orang secara bergantian. Alat musik ini terbuat dari kulit kambing, kapok (Neke fuis), Kijabas yaitu kayu yang berbentuk kecil yang berfungsi untuk mengencangkan kulit, kaba yaitu sejenis tali yang berfungsi untuk mengikat serta mengencangkan kulit hewan tersebut sehingga menghasilkan bunyi yang nyaring. Alat musik ini memiliki ukuran dengan lebar $23 \mathrm{~cm}$ dan diameter pada bagian atas $80 \mathrm{~cm}$, dan bagian bawah $70 \mathrm{~cm}$ dengan tinggi $45 \mathrm{~cm}$.

\section{Deskripsi Pola Ritme Gong Timor}

Arti penting dalam rhythm, yaitu penempatan sebuah tindakan dalam durasi suatu peristiwa yang sedang berlangsung, ritme atau tempo merupakan unsur penting untuk mencapai suatu hasil yang efektif (Wijayanto, dkk 2015). Ritme merupakan perulangan bunyi-bunyian menurut pola tertentu. Musik ritmis merupakan kelompok musik pengiring yang berfungsi sebagai penstabil irama (ketukan) (Ahmadi, 2012). Dengan kata lain ritme adalah pengulangan bunyi secara berulang-ulang. Ritme selalu berkaitan dengan gerakan badaniah, suara, bahasa, nyanyian dan gerakan nada yang dihasilkan oleh alat musik (Prier, 2018:185). Ada empat unsur dalam struktur irama antara lain ketukan, aksen, pola irama, dan birama musik (Suharjana, 2010).

Ritme yang dihasilkan oleh Gong Timor merupakan salah satu ungkapan yang ingin disampaikan melalui simbol yakni kepada leluhur maupun kepada sesama mereka. Alat musik ini dimainkan secara berulang-ulang dari awal hingga akhir dengan tempo dan pukulan ritmik yang berubah-ubah (tidak tetap). Berikut peneliti akan memaparkan bentuk pola ritme dari Gong Timor, sebagai berikut: 


\section{Elemen Irama}

\section{Ketukan}

Ketukan merupakan bunyi yang mendasari pada irama. Ketukan dapat terjadi dalam tempo yang cepat, sedang atau lambat serta dalam tingkatan kecepatan yang tetap maupun berubah-ubah. Hal tersebut dipertegas lagi oleh Benward \& Saker (2008:393) yang menyatakan bahwa tempo adalah kecepatan irama dalam musik, yang dapat dinyatakan secara umum atau dalam ketukan permenit. Gong Timor dalam ritual Tfua Ton dimainkan dengan Vivace yang artinya cepat dan girang dengan kecepatan 160-184 mm, langkah setiap menit seperti yang telah dipaparkan sebelumnya.

Pada Gong Timor pertama Tonu mese bentuk not yang digunakan dalam pukulan ritme tersebut ialah dengan menggunakan bentuk not $1 / 8$ dengan nilai satu ketukan pada pukulan ke satu, lima, enam, tujuh dan delapan pada tiap-tiap birama sedangkan pada bentuk not $1 / 16$ dengan nilai ketukan $1 / 2$ pada pukulan ke dua, tiga dan empat. Gong Timor kedua Ote bentuk not yang digunakan dalam pukulan ritme tersebut ialah menggunakan bentuk not $1 / 8$ dengan nilai ketukan $1 / 2$ pada pukulan pertama sampai pukulan kedelapan. Gong Timor ketiga Kbola, bentuk not yang digunakan dalam pukulan ritme tersebut ialah menggunakan bentuk not $1 / 8$ dengan nilai ketukan $1 / 2$ yaitu pada pukulan ke pertama, kedua, ketiga, kelima, keenam dan ketujuh pada tiap-tiap birama. Gendang (Kée), bentuk not yang digunakan dalam pukulan ritme tersebut ialah bentuk not $1 / 16$ dengan nilai not $1 / 4$ pada tiap ketukan yaitu pada pukulan pertama hingga pukulan ke enambelas.

2. Aksen

Aksen adalah suatu suara keras atau gerakan keras ekstra atau nada-nada tertentu yang diberikan tekanan lebih atau kurang. Tekanan bukan hanya berlaku pada suatu nyanyian saja tetapi pada pukulan ritmik yang dimainkan. Gong Timor merupakan salah satu alat musik tradisi yang dimainkan dalam ritual adat

\section{Tonu Mese}

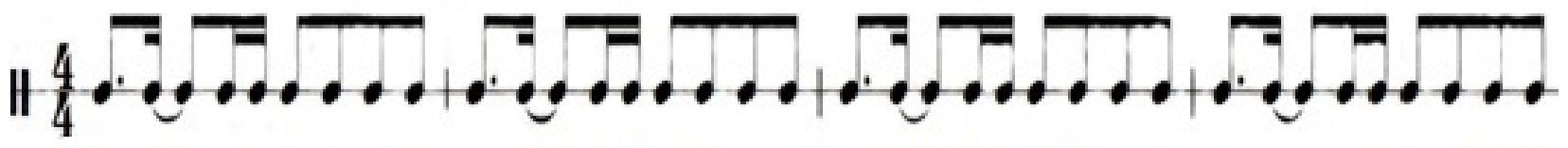

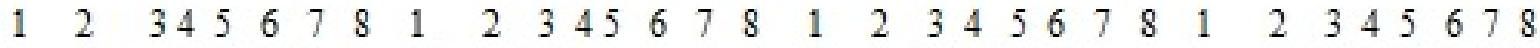
Ote


Kbola

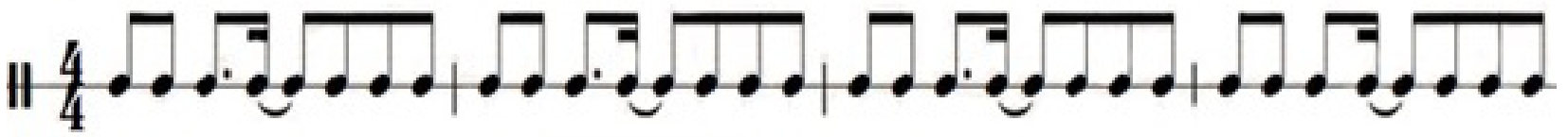

$\begin{array}{llllllllllllllllllllllllllll}1 & 2 & 3 & 4 & 5 & 6 & 7 & 1 & 2 & 3 & 4 & 5 & 6 & 7 & 1 & 2 & 3 & 4 & 5 & 6 & 7 & 1 & 2 & 3 & 4 & 5 & 6 & 7\end{array}$

\section{Gendang ( $\left.\mathrm{Ke}^{\prime} \mathrm{e}\right)$}

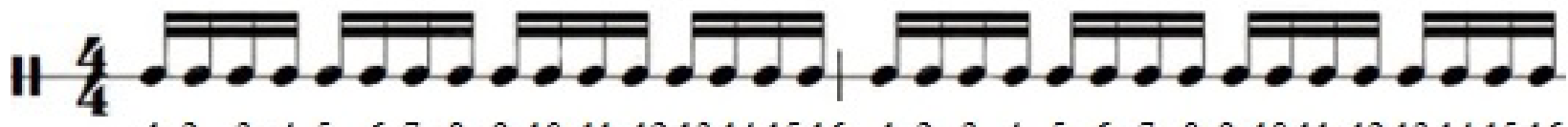

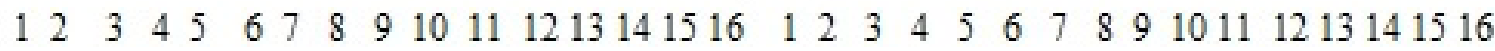
Notasi 1. Pola ritme Gong Timur. (Sumber: Peneliti, 2018) 
secara berulang-ulang, tetapi memiliki aksen yang berbeda pada beberapa bagian tertentu salah satunya ialah tonu mese, ote dan kbola pada ketukan pertama pukulannya lebih keras dibanding ketukan ke 2, 3, dan 4 pada setiap birama sedangkan pada alat musik Gendang tidak terdapat aksen.

\section{Pola irama}

Ritme merupakan elemen waktu dalam musik yang dihasilkan dari durasi dan aksen (Hidayatullah, 2015:9). Gong Timor memiliki satu jenis pola irama dari masing-masing gong seperti yang telah dipaparkan sebelumnya. Bahwa pada Gong Tonu mese, Ote, Kbola dan Gendang memiliki pola irama pada satu birama yang dimainkan berulang-ulang hingga akhir dengan durasi waktu kurang lebih 2-3 menit.

\section{Makna Gong Timor dalam Upacara Ritual Tfua Ton}

Simbol adalah objek, kejadian, bunyi bicara, atau bentuk-bentuk tulis yang diberi makna oleh manusia. Makna simbolik merupakan tanda-tanda yang dapat bermanfaat dalam menyampaikan maksud dan tujuan manusia diberbagai kehidupan manusia. Dalam makna tertentu, simbol seringkali memiliki makna yang mendalam yaitu suatu konsep yang memiliki nilai dalam kehidupan suatu masyarakat (Dodo, 2016). Makna dan musik sebagai sumber daya emosional(Hield \& Price, 2018). Makna dalam musik merupakan ungkapan ekspresi emosional yang dirasakan dan dialami oleh masyarakat khususnya di Desa Napan. Makna dalam upacara adat istiadat merupakan hal yang tidak bisa dijelaskan secara ilmiah maknanya. Makna yang tekandung merupakan harapan baik bagi orang yang melaksanakan upacara adat (Rahimah dkk, 2018). Sesuatu yang memiliki makna itu adalah simbol dan maknanya yang dinyatakan oleh simbol tersebut harus dicari lewat interpretasi atau komunikasi terhadapnya (Herawati, 2010). Makna dalam dunia seni yang disampaikan (Sedyawati, 1995) adalah berkaitan dengan penilaian terhadap seni misalnya seni yang bisa dinikmati, mengguggah imajinasi, dapat menyentuh rasa, dan mampu mewujudkan suatu nilai budaya.
Musik tradisional adalah salah satu cara untuk mengkomunikasikan berbagai macam kepentingan. Yudosaputro (Jazuli, 2014) mengemukakan bahwa kesenian berkedudukan sebagai media komunikasi antara manusia dan manusia, manusia dan alam, manusia dan Maha Pencipta. Ini ditegaskan lagi oleh (Jazuli, 2015) yang menyampaikan bahwa kesenian mempunyai nilai penikmatan sehingga aktivitas seni dapat dikatakan mampu memberikan kesenangan, kebahagiaan, santapan rasa melalui imajinasi setiap orang sesuai tingkat persepsinya. Begitu juga dengan Eli Irawati mengatakan bahwa musik bermakna sebagai alat komunikasi horizontal dan vertikal dalam sebuah upacara ritual (Eli Irawati, 2014:72). Dari penjelasan tersebut bahwa Gong Timor dalam upacara ritual Tfua Ton memiliki nilai-nilai yang terkandung yang dikatakan mampu memberikan kenikmatan, kesenangan, kebahagiaan, kesedihan dan kerja sama yang baik dalam suatu kelompok tertentu.

Makna musik dapat dilihat dari bentuk musik, suara yang dihasilkan dalam hubungannya antara satu dengan yang lain, yang berkembang secara historis melalui paparan informal dan formal untuk musik dan kegiatannya (Green, 2015). Alat musik Gong Timor berbentuk bulat atau bundar yang melambangkan keabadian dan keseimbangan. Pukulan dari alat musik ini merefleksikan koinsidensi antara permulaan dan akhir, antara kelahiran dan kematian. Penjelasan tersebut menunjukan bahwa Gong Timor dalam ritual tersebut mengingatkan kembali akan perjuangan dan kerja keras dalam mempertahankan kehidupan dan juga wilayah mereka dari penjajahan.

Gong Timor dalam ritual Tfua Ton merupakan kegiatan rutinitas yang diadakan setiap tahun sebelum musim tanam dan telah diwariskan pada generasi-generasi berikutnya. Hal ini dikarenakan akan adanya nilai-nilai dan makna yang terkandung didalamnya, musik dalam ritual tidak hanya sekedar untuk dimainkan bahkan dapat mempengaruhi imajinasi dan menjadi penyemangat dalam ritual.

Gong Timor dalam ritual Tfua Ton memiliki simbol komunikasi yaitu untuk memberitahukan adanya bahaya dan kedukaan. Setiap interaksi seseorang dengan orang lain tentu memerlukan mediasi. Mediasi yang merupakan simbol-simbol, 
baik yang melekat pada diri ataupun di luar diri. Tidak semua komunikasi dapat disebut simbol tetapi dalam situasi tertentu setiap benda atau alat dapat ditingkatkan sebagai sebuah simbol ( Rohidi, 2000).

Komunikasi tersebut dimaknai dengan adanya persatuan, kekompakan dan kerjasama antar masyarakat Desa Napan dan terjalin hubungan antara manusia dan leluhur. Gong Timor dalam ritual Tfua Ton sebagai hubungan antara masyarakat Desa Napan, leluhur dan alam, dimana Gong Timor yang dibunyikan dalam ritual tersebut ialah untuk memanggil dan menyapa para leluhur yang telah meninggal untuk hadir bersama-sama dan berkumpul bersama dalam ritual Tfua Ton. Inilah yang menjadi kepercayaan masyarakat Desa Napan yang masih dipegang hingga sekarang ini.

Irama yang dihasilkan oleh Gong Timor menunjukan arti yang berbeda yaitu untuk sebagai keperkasaan "Atoni Pah Meto" dan keberanian dalam suatu tantangan seperti dalam peperangan, masalah perampasan tanah antar suku dan negara Timor Leste pada tahun 1975 dan tahun 1999. Hal ini ditegaskan lagi dalam (Sasi, 2016) bahwa Atoni Pah Meto merupakan kata majemuk yang terdiri dari Atoni (laki-laki dan berarti juga untuk orang atau suku bangsa) pah (tempat atau wilayah) meto (kering atau daratan), maka dapat disimpulkan bahwa Atoni pah meto adalah orang yang mendiami daratan sekaligus nama Penduduk Pulau Timor yang mendiami Kabupaten Timor Tengah Utara.

Ritmik tersebut menunjukan sebuah karakter dan sifat yang dimiliki masyarakat Napan. Irama tersebut juga mengartikan bahwa masyarakat Napan tidak pernah menyerah dan putus asa dalam menghadapi suatu masalah misalnya untuk mempertahankan hidup dengan memperoleh makanan dan minum. Dengan keadaan iklim dan geografis yang kurang mendukung masyarakat terus berjuang dan bekerja keras dalam mengolah lahan mereka untuk bercocok tanam.

\section{Penutup}

Gong Timor merupakan salah satu musik tradisional masyarakat Desa Napan yang terdiri dari beberapa bagian antara lain ialah Gong Tonu
Mese, Ote, Kbola dan Gendang (Ke'e). Gong Timor memiliki bentuk dan ukuran yang berbeda-beda, ini berpengaruh pada bunyi yang akan dihasilkan. Gong Timor tergolong kedalam jenis alat musik ritmis dengan elemen-elemen irama antara lain ialah ketukan, aksen dan pola irama yang dihasilkan. Gong Timor memiliki peran penting dalam upacara ritual Tfua Ton dan telah menjadi satu bagian di dalamnya.

Secara simbolik Gong Timor sebagai simbol keperkasaan, sifat, identitas dan menunjukan karakter masyarakat setempat. Dari simbol-simbol tersebut dapat dimaknai dengan ketidakputusasaan dan tidak pernah menyerah dalam memperjuangkan wilayah dari penjajah serta mempertahankan hidup mereka walaupun dengan keadaan geografis yang kurang mendukung dan tingkat pendidikan yang kurang begitu tinggi. Maka dari itu masyarakat Desa Napan melakukan salah satu ritual Tfua Ton yaitu untuk meminta hujan dan kesuburan tanah kepada Tuhan, leluhur dan alam yang mendiami tempat tersebut.

Gong Timor dalam ritual Tfua Ton memiliki peran penting didalamnya dan tidak dapat dipisahkan. Gong Timor dan ritual Tfua Ton merupakan satu kesatuan. Selain itu juga memiliki kekuatan mistis yaitu untuk memanggil roh-roh para leluhur yang telah meninggal. Gong Timor dalam ritual Tfua Ton merupakan salah satu musik tradisional yang sudah diwariskan turun temurun, ini sebagai salah satu cara untuk menunjukan identitas dan ciri khas dari masyarakat Napan.

\section{Kepustakaan}

Ahmadi, W. L. (2012). Pengembangan Media Pembelajaran Inovatif Kooperatif Musik Ritmis Berbasis Multimedia Di Sma Negeri 3 Pati.Catharsis: Journal of Arts Education, 1(2), 1-5. Retrieved from http://journal. unnes.ac.id/sju/index.php/catharsis

Dodo, S. I. dan T. R. R. (2016). Fungsi Dan Makna Bide Dalam Kehidupan Masyarakat Dayak Kanayatn Di Kabupaten Landak Kalimantan Barat. Catharsis: Journal of Arts Education, 5(2), 123-134. Retrieved from http://journal. unnes.ac.id/sju/index.php/catharsis 
Green, L. (2015). Popular Music Education in and for Itself, and for "Other" Music: Current Research in the Classroom Popular music education in and for itself, and for "other" music: current research in the classroom. International Journal Of Music Education, 24(2), 103-120. https://doi. org/10.1177/0255761406065471

Hield, F., \& Price, S. (2018). "I realised it was the same song ": Familiarisation, assimilation and making meaning with new folk music. International Journal of Traditional Arts, (2), 1-23. Retrieved from www.tradartsjournal. org

Irawati, Eli. 2014. "Makna Simbolik Pertunjukan Kelentangan dalam Upacara Belian Sentiu Suku Dayak Benuaq Desa Tanjung Isuy, Kutai Barat, Kalimantan Timur."Jurnal Kajian Seni, Vol. 1 (1): 60-73. Retrieved from https://sdoi. org/10.22146/art.5876.

Jatmiko, E. M. (2015). Struktur Bentuk Komposisi dan Akulturasi Musik Terbang Biola Sabdo Rahayu Desa Pekiringan, Kecamatan Talang, Kabupaten TegaL. Catharsis : Journal of Arts Education, 4(1), 8-14. Retrieved from http:// journal.unnes.ac.id/sju/index.php/catharsis

Jazuli, M. (2014). Sosiologi Seni : Pengantar dan Model Studi Seni. Yogyakarta: Graha Ilmu.

Jazuli, M. (2015). Pengembangan Kreativitas Seni Budaya Tradisi sebagai Materi Pendidikan Seni. Jurusan Sendratasik Fakultas Bahasa dan Seni Uiversitas negeri Semarang.

Langer, S. K. (1957). Problem Of Art. New York: Ten Philosofical Lecture.

Prier, K.-E. (2018). Kamus Musik. Yogyakarta:
Percetakan Rejeki Yogyakarta.

Rahimah, H. dan D. (2018). Kajian etnobotani (upacara adat suku aceh di provinsi aceh). Jurnal Biotik, 6(1), 53-58.

Rohidi, T. R. (2000). Kesenian dalam Pendekatan Kebudayaan. Bandung: STISI Press Bandung.

Sasi, D. (2016). Perubahan budaya kerja pertanian lahan kering. Jurnal Kajian Budaya, 6(2), 145164. https://doi.org/10.17510/paradigma. v6i2.94

Sedyawati, E. (1995). “Konsep dan Implementasi Pendidikan Seni”. Makalah disampaikan pada Seminar Nasional IKIP Semarang.

Suharjana, F. (2010). Aktivitas ritmik dalam pendidikan jasmani di Sekolah Dasar. Pendidikan Jasmani Indonesia, 7(1), 1-16.

Sunarman, Y. B. (2010). Bentuk Rupa Dan Makna Simbolis Ragam Hias Dan Pura Mangkunegaran Surakarta. Universitas Sebelas Maret.

Tindaon, Rosmegawaty, GR Lono Lastoro Simatupang, Victor Ganap, dan T. H. (2018). Anndung-Andung Mate di Ranto. Resital: Jurnal Seni Pertunjukan, 19(2), 46-53.

Triyanto. (2018). Belajar dari kearifan Lokal Seni pesisiran. Semarang: Cipta Prima Nusantara.

Vuust, P., Ostergaard, L., Johanne, K., Bailey, C., \& Roepstorff, A. (2009). Predictive coding of music - Brain responses to rhythmic incongruity. CORTEX, 45(1), 80-92. https:// doi.org/10.1016/j.cortex.2008.05.014.

Wijayanto, Bayu, G.R. Lono, L. S. dan V. G. (2015). Strategi Musikal dalam Ritual Pujian dan Penyembahan. Jurnal Resital, 16(3), 125140. Retrieved from http://journal.isi.ac.id/ index.php/resital/article/view/1678/450. 